\title{
Students' Voices on the Teaching of Higher Order Thinking Skills Through WhatsApp-mediated EFL Online Discussion
}

\author{
Amrin Hasibuan*, Sri Setyarini, Pupung Purnawarman \\ English Education Study Program, Universitas Pendidikan Indonesia \\ "Corresponding author.Email: amrinhasibuan018@upi.edu
}

\begin{abstract}
There has been a significant rise in the use of social media as platforms for online teaching and learning during the Covid-19 pandemic. WhatsApp as one of learning platforms used by many institutions has given a high contribution in supporting the success of the online learning. The aim of this study is to investigate how students perceive the teaching of higher order thinking skills (HOTS) through EFL online discussion mediated by WhatsApp application. To achieve this aim, Anderson and Krathwohl (2001) model was used by focusing on analysing, evaluating and creating. A set of questionnaire and interview list were used. The result showed the rise of students' critical thinking and students' perception about online discussion by using WhatsApp as an appropriate platform for learning and thinking. Furthermore, it is recommended that in order to make this online discussion more effective, the role of teachers as facilitator should be continuously increased.
\end{abstract}

Keywords: Higher order thinking skills, online discussion, WhatsApp

\section{INTRODUCTION}

Since the early year of 2020, the spread of Covid-19 pandemic has been massive, and the pandemic has infected almost every country in the world. Millions of people are now infected and more than 14,000 have died in Indonesia caused by the pandemic. A number of countries apply lockdown and quarantine to cut the spread of the Covid-19 pandemic. Consequently, many companies and schools are closed and suggested to study at home and work from home. People are requested to apply a new way of life called new normal by applying health protocols such as social distancing, wearing masks, and using hand sanitizers. Teaching and learning activities are strongly recommended to conduct online.

The disruption caused by the virus not only impacts on sector of health, economic and social but it also has changed the face of our education world. Data from UNESCO reported that more than 1.2 billion children in 186 countries were affected by school closures and several other countries have implemented localized closures impacting millions of additional learners due to the pandemic. Based on a report from the World Bank, in Indonesia there are more than 530.000 school closures caused by the Covid-19 outbreak and affecting 68 million students from pre-primary through tertiary levels. Anticipating this situation, the Ministry of Education and Culture has made a policy that is the implementation of online or distance learning for teachers and students. In response to the policy and significant demand of online learning media, many online learning platform providers offer either free or paid access to their services. The use of common online learning microblogging platforms such as Google classroom, Quipper, Edmodo, Google Suite for Education, WhatsApp, and YouTube becomes solution implemented in many schools (Daheri, Juliana, Deriwanto, \& Amda, 2020). Even local online learning platforms such as Ruangguru, Rumah belajar, Zenius and Cakap are also offered as learning media. Traditional classroom education model seems to have been gradually left behind and the era of digital or online learning emerges as the solution implemented in teaching and learning environment.

The era of Industrial Revolution 4.0 opens opportunities for human resources to improve their life. Technology offers ease and broad accessibility for the exploration of all potentials. The impact of Industrial Revolution 4.0 may occur to all sectors included education. Education in this era (Education 4.0) characterizes a digital technology utilization in learning 
process and make it run beyond time and place continuously. It means that technology plays a significant role to create creative learners which have 21 st century skills namely Critical Thinking, Collaboration, Communication, and Creativity. All changes taking place due to the technology have to be anticipated by educational stakeholders. Schools as educational institution should be able to implement the elements of information technology in their educational activities either in learning process or school management. In this point, teachers play a crucial role. The way teachers teach has to be changed as face-to-face learning system during the Covid-19 pandemic cannot be done anymore. Teaching and learning method have shifted to a digital based learning in which technology has taken its place in education. Educational technology offers various instructional tools and learning platforms in form of social media applications or other educational technologies. One of the most popular and accessible applications is WhatsApp messenger. WhatsApp is a smartphone application intended for sending instant messages both personally and in group that enables users to send or share text, voice, video calls, images, documents, user location, and other media. The messages are sent through an internet data connection. In Indonesia WhatsApp is one of top ranks and of the most active social media after YouTube with the penetration of $83 \%$ (Hootsuite, 2019). It means that $83 \%$ internet users in Indonesia or 124 million users listed actively use WhatsApp on their gadgets. Along with the advance of educational technology amid the Covid-19 pandemic, the use becomes more significant since teaching and learning activities are conducted at home. At the same time, the government recommends several learning platforms as the solution to serve the purpose. This situation makes WA become more popular to use and this is in line with the data mentioned previously in which $83 \%$ internet users in Indonesia actively use WhatsApp on their gadgets. The potential of WA is not only due to its easily downloaded application but also for its flexibility and various features to send text, video, audio, links, documents, location, and pictures (Susanti \& Tarmuji, 2016).

Some studies have been conducted in the utilization of WA in English language teaching. Justina (2016) reveals that WhatsApp is very helpful for language teachers to identify what their learners enjoy when doing and utilize it to engage them in language development, especially reading and writing. Savan (2016) in her research, found that WhatsApp use for improvement of achievement of the course goals and has a significant support of the teacher candidates Kheryadi (2018) states that using WhatsApp as one of the tools is useful to help students in communicative language learning. In line with this view, Hamad (2017) also asserts that WhatsApp can increase students' learning and enthusiasm, and help students encourage their English language skill. The use of online media like WA in learning English in high school can make students do more learning activities such as observation, demonstrating, project making and so on. Furthermore, the opportunities facilitated by WA in online learning not only for the purpose of communication and sharing information. WA can open the opportunity for collaboration and cooperation between teachers and students (Barhoumi \& Rossi, 2013). Its potential may support the development of Higher Order Thinking Skills (HOTS) such as for inquiry, creativity, critical thinking, reflection and dialogue (Subran, 2013). The collaboration and interaction give students the opportunity for negotiation of meaning in course content and promote social learning and critical thinking. Kanuka and Garrison (2004) support this view. They state that online discussion can facilitate higher order thinking. This is also in line with the view of Kaplan and Kies (1994). They argue that asynchronous communication allows students to have more participating to reflect on what others have said and how they wish to respond. At this point, the teaching of online discussion by using WA to facilitate higher order thinking is still seldom practiced. It becomes the source of failure in education in Indonesia because of the lack of innovation and creativity by using social media especially WA as learning platform. That's why the author makes an effort to investigate how EFL students perceive the learning of HOTS mediated by WhatsApp application. Thus, for more specifically, the research questions of this study are as follows:

(1) What is the usefulness of WhatsApp application for EFL online discussion?

(2) How do students perceive the learning of higher order thinking skills through online discussion mediated by WhatsApp application.

\section{LITERATURE REVIEW}

\subsection{Online Discussion}

Online discussion is an e-learning platform that allows students to post messages to the discussion threads, interact and receive feedback from other students and teacher for deeper understanding (Balaji \& Chakrabarti, 2010). Scholars have discussed the benefits and concepts of online discussion in promoting critical thinking. Landis, Swain, and Friche (2007) argue that online discussion (OD) provides better cognitive and exploratory learning. It means that if OD is effectively practiced, it will improve the level of thinking. DeLoach and Greenlaw (2014) support this view. They state that students' high levels of critical thinking skills will increase when instructors use effective questioning and moderating skills. They note that students' arguments tend to increase in response to the quality of the responses they receive from their peers. Similar to what Shapley, Sheehan, Maloney, and Walker state that OD may 
provide upgraded critical thinking skills. Wilson, Pollock, and Hamann (2007) investigate the benefits of OD and how it promotes active learning behaviours and improves learning outcomes.

\subsection{WhatsApp and Its usage}

WhatsApp is a smartphone application intended for sending instant messages both personally and in group that enables users to send or share text, voice, video calls, images, documents, user location, and other media. Church and de Oliveira (2013) said that people use this application due to its low cost, the possibility of a fluent conversation, the sense of belonging to a group that creates a feeling of community and family, and the confidentiality maintained, unlike social networks. Anglano (2014) adds that WhatsApp gives its users with various forms of communications, namely user to user communications, broadcast messages, and group chats. In accordance with students' perception to the use of WA in learning processes, some studies have been examined. For example, a study result conducted by Malecela (2016) proved that students believed WA is helpful in online learning by facilitating communication with other peers and instructor. Beside its basic features for communication and sharing information, WA also has collaborative features that can be used to facilitate higher order thinking such as multimedia, unlimited messaging and cross platform engagements (Bere, 2012). Furthermore, the potential of WA to facilitate HOTS is also emphasized by Subran (2013). He says that the development of HOTS can be supported by its inquiry, creativity, critical reflection, and dialogue.

\subsection{Higher order thinking skills}

In term of thinking skill, Bloom's taxonomy is considered as a basis for higher order thinking skills. In its journey, Anderson and Krathwohl (2001) then revise the taxonomy by classifying it into: remember, understand, apply, analyse, evaluate, and create. The table 1 below shows their notion about critical thinking as follows:

Table 1 Bloom' Taxonomy Revision by Anderson \& Krathwohl (2001)

\begin{tabular}{llll}
\hline Knowledge & \multicolumn{3}{c}{ Cognitive Process Dimension } \\
\cline { 2 - 4 } Dimension & C4 Analyse & C5 Evaluate & C6 Create \\
\cline { 2 - 4 } Factual & $\begin{array}{l}\text { Making } \\
\text { structure }\end{array}$ & $\begin{array}{l}\text { Comparing, } \\
\text { correlating }\end{array}$ & Joining \\
Conceptual & Classifying, & Examine, & Planning \\
& Explain & Interpret & \\
Procedural & Analyse, & Conclude, & Arrange, \\
& Distinguish & Resume & Formulate \\
\hline
\end{tabular}

Brookhart (2010) defines HOTS into three categories: transfer, critical thinking, and problem solving. Transfer means that students not only remember but also make sense and able to use what they have learned. Norris and Ennis (1989) define critical thinking as reflective thinking that is focused on the consideration of what to believe or what to do. Barahal (2008) views that it includes reasoning, questioning, investigating, observing, describing, comparing and connecting. Meanwhile, Nitko and Brookhart (2007) define problem solving as a process of achieving a goal by using one or more higher order thinking processes.

\section{METHODS}

'This study employed qualitative approach with survey research method using questionnaire and student interview. Classroom meeting session was conducted to introduce and explain everything related to HOTS and rules or guidelines as well. The classroom meeting applied Health protocols due to the Covid-19 pandemic. The research involved 31 high school students (10 males and 21 females) of eleventh graders in a public high school in Riau. They are all enrolled in the academic year of 2020-2021. All of the participants in this research have experiences in online learning environment especially in English subject during the Covid-19 pandemic. Students are accustomed to use WA application for online learning. All of them have smartphone and installed WA application.

In terms of data collection, the data were collected through multiple sources such as questionnaire, students' interview, and students' postings on WA group (WAG). The questionnaire consists of 22 questions with two themes namely the usefulness of WA for online learning and HOTS and collaboration. The participation rate of respondents reached $93,5 \%$ in which 29 completed the questionnaire Previously, students' WA phone numbers were collected to create WAG. From the WAG, the instructor shared two question items in the form of argumentative questions equipped with pictures to provoke student responses. Before students were provided the questions on WAG, the instructor made classroom couching to introduce and elaborate rules and guidelines when they had their online discussion. In the rules and guidelines, the instructor elaborated what students have to do and what they can't and the consequences they receive when they break the rules. For example, students are prohibited to use impolite words or expression, If this happens, they will be removed from WAG. Furthermore, in the classroom meeting session with students, the instructor also gave short introduction of the benefits and usage of higher order thinking skills. The face-to-face session was conducted for five days with various activities such as introducing the 21 st century learning, elaborating HOTS and its examples and doing exercise items as well. This is intended to make a 
HOTS friendly relationship with students. After the materials were adequately explained, students were then provided two HOTS based items after one day students got home. Students can choose one of the items which they consider representing their feeling and ability. For triggering students' responses become more deeply and sharper, they were highly suggested to post not only their answers but also provide comments on their peers' postings. Students' answers and comments were written at least one paragraph. When they conducted this well, the instructor gave more scores for them as incentive or bonus. Students' answers have to be posted on WAG three days after the questions were sent by the instructor. But if they have time problem, the instructor gave them dispensation for one or two more days. Such a long time intended to give students sufficient time to post and make responses to postings. All students' posted answers had to be written in English.

Students' interview session was audio recorded and transcribed verbatim. The interviews were conducted in students' native language that is Bahasa Indonesia to make students more comfortable in expressing their feeling and opinions. The interview session was directly conducted face to face in the school. Content analysis in students' postings were used to code and categorize the cognitive processes. Because the interview questions were typed on laptop, the interviewer used it to take all responses from the respondents and typed them on Microsoft Word 2010. During the interview session, randomly selected participants were interviewed in order to probe deeper students' responses. There are two themes of interview questions addressed to students: the usefulness of WhatsApp for online learning and critical thinking and collaboration. Both types of questions were adapted from other the researchers. It took 15 minutes for each theme questions during the interview session. Before the instructor shared the items on WAG, short instructions were provided about how to do the items such as the way to answer, the length or deadline of items gathering or other miscellaneous problems appearing during the discussion.

\section{FINDINGS AND DISCUSSION 4.1. Data analysis}

In this study, the findings focused on two things: students' perception on the usefulness of WhatsApp for English learning. And how student perceive the learning of higher order thinking skills in online discussion of English subject mediated by WhatsApp. This study used a Likert type scale for the measurement used in the questionnaire as follows:
1. Strongly disagree
2. Disagree
3. Moderate
4. Agree
5. Strongly agree

\subsubsection{The usefulness of WhatsApp for EFL online discussion}

The first research question is on the usefulness of WhatsApp application for EFL online discussion. A survey analysis was used to represent participants' data and to answer the research question. The result of the analysis is shown in Table 2 below.

Based on the questionnaire data, most of the participants reported using WA with average of $1-3$ hours per day and used it for the purposes of communication at any time and of sharing chats, videos, pictures, and stickers.

Table 2 below demonstrated that from all the items, students gave the highest attention $(74.2 \%)$ to the beneficial information obtained via WA online learning. But there is an interesting point related to students' opinions regarding whether learning using WA is fun and gave motivation. Students stated that both the opinions were moderate $(62.5 \%)$. Meanwhile, when the students were asked about the effectiveness of learning English using WA, $29 \%$ of them disagreed and $48.4 \%$ stated their agreement. In terms of the ability of English writing can be improved using WA, 38.7\% the students agreed and $35.5 \%$ of them were reported moderate. Overall, all the findings showed the usefulness of WA for EFL online

Table 2. The usefulness level of WhatsApp

\begin{tabular}{lccccc}
\hline \multicolumn{1}{c}{ Items } & 1 & 2 & 3 & 4 & 5 \\
\hline $\begin{array}{l}\text { 6. Through WA, I can share beneficial information for learning } \\
\text { 7. Learning English through WA is fun }\end{array}$ & - & - & - & $23(74,2 \%)$ & $6(19,4 \%)$ \\
8. Learning through WA can improve my English ability & $6(19,4 \%)$ & $4(12,9 \%)$ & $17(54,8 \%)$ & $2(6,5 \%)$ & - \\
$\begin{array}{l}\text { 9. Learning through WA my vocabulary can add more. } \\
\text { 10. Learning using WA can increase my motivation. }\end{array}$ & $2(6,5 \%)$ & $2(6,5 \%)$ & $12(38,7 \%)$ & $13(41,9 \%)$ & - \\
11. Learning through WA effectively improves my English ability & $1(3,2 \%)$ & $9(29 \%)$ & $15(48,4 \%)$ & $3(9,7 \%)$ & - \\
\begin{tabular}{l} 
12. My ability in English writing improves by using WA. \\
\hline
\end{tabular} & $3(9,7 \%)$ & $3(9,7 \%)$ & $11(35,5 \%)$ & $12(38,7 \%)$ & - \\
\hline
\end{tabular}


learning did not reach the optimum rate of $50 \%$ yet but tend to be a very positive acceptance.

\subsubsection{Students' perception on how student perceive the learning of higher order thinking skills in online discussion of English subject mediated by WhatsApp}

In this second theme, there are 10 question items asked to the participants. Table 3 shows that $62.5 \%$ of the students agreed that HOTS items shared by instructor should be actual issues to provoke students' critical thinking. $35.5 \%$ of the students also expressed their need to have more time to complete the responses and comments. In term of students' engagement, $32.3 \%$ of students did not feel engaged in online discussion using HOTS concept. This critical point should be a signal for teachers for the next treatment as a reflection and input. Similarly, when the students were asked about online discussion using WA could improve their reasoning and critical ability, $45.2 \%$ stated it in the rate of moderate. This point is higher than the participants' agreement to the question. For the questions number 20 and 21, the participants had similar responses in which they did not reveal their disagreement. In the other word, all participants agreed that online discussion via WA can reduce their shy feeling and felt more freedom. Overall, the findings showed that there are many problems that have to be improved and corrected by instructor such as collaboration and engagement because the scores are below $50 \%$. But some elements of HOTS have been fulfilled. In fact, $61.3 \%$ of students agreed to apply this method to other subjects.

\subsection{The interview results}

The interview session was conducted in face-to-face classroom activity by applying health protocols. There are 9 questions which consist of two items namely the usefulness of WA in online learning and students' perception on the online discussion of HOTS via WA application. The result was that all students gave the same opinions revealing that learning using WA was very useful. But majority of the students felt that the learning cannot improve their English productively since they got less responses from instructor. This reason also caused them less active in language activity. One of them said:

"No, I am not, because this makes me lazy when the teacher gives me no response to my problems ".

Furthermore, in terms of higher order thinking question asked to the students whether the interaction in online discussion via WA gave them benefits, one of them said, "of course, that makes me know my mistakes and can exchange ideas with friends". Most of the students said that they were able to give more opinions when they were requested to give comments other students' answers. Even one or two students gave more than two responses to his friend' $s$ answer. In terms of collaboration during the discussion, most of the students agreed that it made them think critically and caused them to know good or bad their friends' answers.

\section{CONCLUSION}

From the two research questions discussed above, the result showed students' agreement of the effectiveness of WhatsApp for online learning and discussion. But for the appearance of critical thinking and collaboration, instructors need to provide actual or burning topics happening around the students. However, the instructors' presence plays a vital role to keep students' motivation stay engaged in the online discussion. Some challenges and problems are found in which during the Covid-19 pandemic the instructors should be more creative and innovative. They have to serve something different to

Table 3. Students' perception on the level of critical thinking

\begin{tabular}{lccccc}
\hline \multicolumn{1}{c}{ Items } & 1 & 2 & 3 & 4 & 5 \\
\hline $\begin{array}{l}\text { 13. WA online discussion with HOTS may improve my English } \\
\text { 14. Peer collaboration during discussion makes me think critically. }\end{array}$ & $1(3.2 \%)$ & $6(19.4 \%)$ & $4(12.9 \%)$ & $23(74.2 \%)$ & $3(9.7 \%)$ \\
$\begin{array}{l}\text { 15. HOTS items on WA group was very actual that make me think } \\
\text { critically. }\end{array}$ & - & $4(12.9 \%)$ & $8(25.8 \%)$ & $14(45.2 \%)$ & $3(9.7 \%)$ \\
$\begin{array}{l}\text { 16. Time given for answering the questions and comments was } \\
\text { sufficient. }\end{array}$ & $1(3.2 \%)$ & $11(35.5 \%)$ & $1(3.2 \%)$ & $16(51.6 \%)$ & $1(3.2 \%)$ \\
$\begin{array}{l}\text { 17. Online discussion with WA can improve my reasoning and } \\
\text { critical thinking ability. }\end{array}$ & $1(3.2 \%)$ & $4(12.9 \%)$ & $14(45.2 \%)$ & $10(32.2 \%)$ & - \\
$\begin{array}{l}\text { 18.Online discussion with WA made me able to debate ideas and } \\
\text { exchanged my opinions }\end{array}$ & $3(9.7 \%)$ & $3(9.7 \%)$ & $9(29 \%)$ & $11(35.5 \%)$ & $3(9.7 \%)$ \\
19.Online discussion with WA using HOTS made me engaged in & $2(6.5 \%)$ & $10(41.9 \%)$ & $1(3.2 \%)$ & $13(41.9 \%)$ & $3(9.7 \%)$ \\
learning \\
$\begin{array}{l}\text { 20. Online discussion with WA reduced anxiety when } \\
\text { communicating with the teacher. }\end{array}$
\end{tabular}


their students by applying a technology-based learning. It is also recommended for further studies related to the use of social media especially WhatsApp for online learning.

\section{ACKNOWLEDGMENTS}

The author would like to greatly thank Dinas Pendidikan the province of Riau and co-authors for their contributions and support on this study. Special thank is also delivered to the committee of Conaplin for their hard effort in organizing this event.

\section{REFERENCES}

Anderson, L. W., \& Krathwohl, D. (2001). A taxonomy for learning, teaching, and assessing: A revision of Bloom's taxonomy of educational objective. Longman.

Anglano, C. (2014). Forensic analysis of WhatsApp messenger on android smartphones. Digital Investigation, $\quad 11(3), \quad 201-213$. http://doi.org/10.1016/j.diin.2014.04.003

Balaji, M. S., \& Chakrabarti, D. (2010). Student interaction in online discussion forum: Empirical research from media richness theory. Perspective Journal of Interactive Online Learning, 9(1), 122.

Barahal, S. L. (2008). Thinking about thinking. Phi Delta Kappan, 90(4), 298-302. https://doi.org/10.1177\%2F00317217080900041 2

Barhoumi, C. \&.Rossi, P. G. (2013). The effectiveness of the instruction oriented hypertext systems compared to direct instruction in e-learning environment. Contemporary Educational Technology, 4(4), 281-308.

Bere, A. (2012). Comparative study of student experiences of ubiquitous learning via mobile devices and learner management systems at a south african university. Proceedings of the 14th Annual Conference on World Wide Web Application. Durban

Brookhart, S. M. (2010). How to assess higher-order thinking skills in your classroom. Virginia, USA: ASCD.

Church, K., \& de Oliveira, K. R. (2013). What's up with WhatsApp? Comparing mobile instant messaging behaviors with traditional SMS. Proceedings of the 15th international conference on Human Computer interaction with mobile devices and services, 352 -361.
Daheri, M., Juliana, J., Deriwanto, D., \& Amda, A. D. (2020). Efektifitas WhatsApp sebagai media belajar daring. Jurnal BASICEDU, 4(4), 775-783.

Hamad, M .M. (2017). Using WhatsApp to enhance students' learning of English language experience to share. Higher Education Studies, 7(4), 74 -87.

Hootsuite. (2019). The global state of digital in 2019. https://www.hootsuite.com/resources/digital-in2019

Justina, M. (2016). Use of whatsapp to enhance reading and writing skills at undergraduate college level. Journal of Language in India, 16, 47-60.

Kanuka H., \& Garrison. D. R. (2004). Cognitive presence in online learning. Journal of computing in higher education, 15(2), 21.

Kaplan, E. J., \& Kies, D .A. (1994). Strategies to increase critical thinking in the undergraduate college classroom. College Student Journal, 28(3), 2431 .

Kheryadi, K. (2018). The implementation of "WHATSAPP" as a media of English language teaching. Loquen: English Studies Journal, 10(2), $1-14$.

Landis, M., Swain, K. D., \& Friche, M. J. (2007). Evaluating critical thinking in class and online: comparison of the Newman method and the Facione rubric. Communication Disorders Quarterly, 28(3), 135-143.

Malecela, I. O. (2016). Usage of whatsapp among postgraduate students of Kulliyyah of Education, International Islamic University Malaysia. International Journal of Advanced Engineering Research and Science, 3(10), 126-137. https://doi.org/10.22161/ijaers/310.21.

Nitko, A. J., \& Brookhart, S. M. (2007). Education assessment of students. New Jearsey: Merrill Prentice Hall.

Norris, S. P., \& Ennis, R. H. (1989). Evaluating critical thinking, the practitioner's guide to teaching thinking series. Eric.

Sayan, H. (2016). Affecting higher students learning activities by using WhatsApp. European Journal of Research and Reflection in Educational Sciences, 4(3), 88-93.

Shapley, K., Sheehan, D., Maloney, C., \& Walker, F. C. (2011). Effects of technology immersion middle school students' learning opportunities and achievement. The journal of Educational Research, 104(5), 299-315. 
Subran, D. (2013). Developing higher-order thinking with ICT (Unpublished $\mathrm{PhD}$ dissertation). The University of West Indies.

Susanti, A., \& Tarmuji, A. (2016). Techniques of optimizing whatsapp as an instructional tool for teaching EFL writing in Indonesian Senior High Schools. International Journal on Studies in English Language and Literature, 4(10), 26-31. http://doi.org/10.20431/2347-3134.0410005

Wilson, B. M., Pollock, P. H., \& Hamann, K. (2007). Does active learning enhance learner outcomes? Evidence from discussion participation in online classes. Journal of Political Science Education, $3(2), 131-142$. 